\title{
Katarzyna Bachnik
}

Warsaw School of Economics

e-mail: katarzynabachnik@gmail.com

\section{SMALL AND MEDIUM ENTERPRISES'}

APPROACH TOWARDS CSR: EMPIRICAL STUDY

\section{PODEJŚCIE MALYCH I ŚREDNICH}

PRZEDSIECBIORSTW DO SPOLECZNEJ

ODPOWIEDZIALNOŚCI BIZNESU (CSR):

BADANIE EMPIRYCZNE

DOI: $10.15611 / \mathrm{pn} .2017 .464 .01$

JEL Classification: M1

Summary: SMEs face a challenge of responding to inescapable changes as a result of various internal and external factors. As they attempt to cope with the changing conditions, they might face attitudinal and behavioral shifts. They need to develop new ways of thinking about their operations and dealing with various groups of stakeholders. Adoption of more sustainable approach might contribute to the success of a company in terms of cost impact, innovation impact, environmental impact and stakeholder impact. The aim of the article is to define the degree to which SMEs understand ideas behind corporate social responsibility (CSR) and to determine the degree of maturity of SMEs with regard to CSR. Of particular interest is to identify the dimensions of CSR engagement and to verify which component: social, environmental or economic, plays a dominant role for SMEs, which will further inform about the fact whether CSR has operational or rather strategic character. The article presents selected results of empirical research conducted by the Institute of Management at Warsaw School of Economics in 2016.

Keywords: SME, CSR.

Streszczenie: Na skutek występowania różnych sił wewnętrznych i zewnętrznych, sektor MŚP musi odpowiednio reagować i doskonalić zdolności adaptacyjne. Może to oznaczać konieczność wprowadzania pewnych zmian o charakterze behawioralnym. MŚP muszą rozwinąć nowe sposoby myślenia o podejmowanych działaniach, w tym o budowaniu relacji z różnymi grupami interesariuszy. Przyjęcie bardziej zrównoważonego podejścia, które rzutuje na politykę cenową, stopień innowacyjności, stopień oddziaływania na środowisko naturalne i orientację na interesariuszy, może przyczynić się do sukcesu firmy. Celem artykułu jest określenie, w jakim stopniu sektor MŚP rozumie ideały stojące za koncepcją społecznej odpowiedzialności biznesu (CSR) oraz jak można ocenić stopień dojrzałości podejścia w odniesieniu do CSR. Środkiem do tego celu jest określenie, który składnik: społeczny, środowi- 
skowy lub gospodarczy odgrywa dominującą rolę dla MŚP, co dodatkowo sugeruje, czy CSR ma charakter operacyjny czy raczej strategiczny. W artykule przedstawiono wybrane wyniki badań empirycznych przeprowadzonych przez Instytut Zarządzania Szkoły Głównej Handlowej w Warszawie w 2016 roku.

Słowa kluczowe: MSP, CSR.

\section{Introduction}

Considerations on CSR are usually carried out from the point of view of large corporations. At the same time these are small and medium enterprises (SMEs) that dominate Polish economy. Sustainable future requires sustainable societies and SMEs within an environment that is resilient. [Sheehan 2013] To make it happen, innovative products are to be designed, new markets are to be found, age-old business problems are to be solved, public understanding shall be improved and sustainable brands shall be strengthened. SMEs face a challenge of responding to inescapable changes as a result of various internal and external factors. As they attempt to cope with the changing conditions, they might face attitudinal and behavioral shifts. They need to develop new ways of thinking about their operations and dealing with various groups of stakeholders.

Adoption of more sustainable approach might contribute to the success of a company in terms of cost impact, innovation impact, environmental impact and stakeholder impact. Sustainability can be located at the intersection of risk, natural resource-based view and shared value. [James 2015] A company needs to incorporate environmental and social impact and its effect on cost structure and revenue streams. Sustainability shall contribute to organizational strategy through pollution prevention, product stewardship and sustainable development. Thinking of creating shared value shall assist the company in the mitigation of environmental impacts arising from value chain activities, but it may also lead to sustainability-driven innovations.

The aim of the article is to define the degree to which SMEs understand ideas behind corporate social responsibility (CSR) and to determine the degree of maturity of SMEs with regard to CSR. Of particular interest is to identify the dimensions of CSR engagement and to verify which component: social, environmental or economic, plays a dominant role for SMEs, which will further inform about the fact whether CSR has operational or rather strategic character. Thereby, the article tries to answer the following research questions:

- How small and medium-sized enterprises understand the idea of sustainable development?

- What is being done by SMEs to carry out the strategy, through the prism of the indicated motives and what specific tools are used?

- What is the level of executed or intended CSR activity of SMEs? 
The article presents selected results of empirical research conducted by the Institute of Management at Warsaw School of Economics in 2016 on a sample of 153 SMEs. This was CATI method.

\section{Understanding of CSR concept}

Using the definition of the European Commission we should recognize that CSR is "the responsibility of enterprises for their impact on society". [EC 2011] This is a concept whereby companies at the stage of strategy building voluntarily take into account the social interests and environmental protection, as well as the quality of relationships with various stakeholder groups. In this sense, being responsible is not limited only to the fulfilment of formal and legal requirements, but also includes investments in human resources, environmental protection and building relationships with the environment. [Bachnik 2016] This is a direct reference to the triple bottom line defined by J. Elkington. [Elkington 2004; Elkington, Zeitz 2014; Savitz, Weber 2014] The study shows that three of the eight options presented in the cafeteria received by far the largest percentage of indications (see Figure 1). The largest group of respondents (31\%) understand the idea of sustainable development

Implements social issues in decision making
Implements environmental issues in decision
making
Implements economic issues in decision making
Implements social and environmental issues in
decision making
Implements environmental and economic issues
in decision making
Implements social and economic issues in
decision making
Implements social, environmental and economic
issues in decision making
Does not take into account sustainability ideas in
decision making

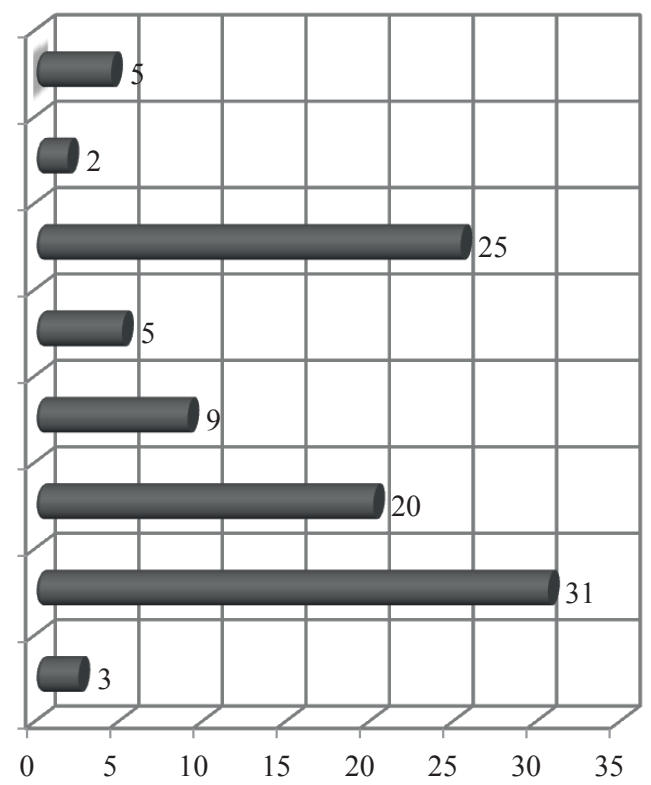

Figure 1. How do your company understand the concept of sustainable development? It means that the company: [\% of answers]

Source: empirical study, Institute of Management, Warsaw School of Economics 2016, n = 153. 
as taking social, environmental and economic causes into account while making decisions. This is a positive observation. Almost every third respondent is aware of the economic, social and environmental dimension of conducting business. Every fourth respondent (25\%) stated that the most important are economic issues, and one in five that these are social and economic ones. A common feature of these three most frequently chosen options is the economic dimension, which in the decisionmaking processes of enterprises should be considered with respect to sustainability. Nevertheless, viability of the market and relatively high profitability of business seems absolutely crucial for SMEs. As economics determines market existence of SMEs which usually have no support in the form of financial security, human resources or another key area of specialization - as it is often the case for Polish subsidiaries of large international corporations - it is hardly surprising that it is seen as a sine qua non condition of thinking about business in other dimensions. The least respondents highly consider in this aspect social (5\%) and environmental issues ( $2 \%$ ). Just $2 \%$ of respondents acknowledge that they do not take into account sustainability in decision-making processes.

There are no major deviations from the general distribution of respondents' answers, as presented in Figure 1, if we break them into particular information about the enterprises, such as 1) industry, 2) ownership, 3) capital structure, 4) range of operations and 5) number of employees. If you look at the results due to the industry, trading companies more often point to the environmental dimension than the manufacturing and service companies. It is a good sign that few companies, regardless of industry, do not include the concept of sustainable development in their decision-making processes. Capital structure has some significance. Most companies with the majority of Polish equity (67\%) admitted that they took into account more than one dimension of conducting business in their decision making, while $50 \%$ of companies with majority of international capital focused on either social or environmental or economic causes. The range of operations and the number of employees did not differentiate responses significantly.

\section{Activities undertaken by SMEs}

Apart from the pure understanding of CSR, it is worth verifying whether SMEs follow CSR path proactively: what kind of activities they actually pursue. The respondents were to prioritize various options (see Figure 2).

There are no such big discrepancies in the response rate here in comparison to data illustrated in Figure 1. Still the largest number of respondents (30\%) claim that they act ethically and this is enforced within the whole organization. The second largest percentage of respondents (24\%) takes into account expectations of stakeholders. Some variation of answers among respondents may indicate other priorities that shape the strategy being implemented and that affect what kind of actions are ultimately 
chosen in order to support strategy implementation. As all suggested options are important for doing business successfully in the long term, most responses in the first place indicating ethical behavior can be dictated by the fact that this option may be interpreted broadly. A company that acts ethically, can in effect make decisions that follow law regulations and international business conduct law or that lead to the minimization of the negative influence of its actions to environment.

While only $8 \%$ of respondents try in the first place to strengthen the positive impact of its operations to environment, $24 \%$ give higher priority to stakeholders and their expectations. These statements confirm that SMEs must be firmly rooted in the specifics of the market by securing the networks, consisting of different interest groups. Building and maintaining long-term business relationships is particularly important to SMEs, both for the creation of opportunities for further development and for the design of appreciated image among various communities. Such a distribution of responses may also be dictated by accepting customer orientation by several companies. Their decisions and accepted business solutions are then related to the needs and preferences of the customers. The turn towards customers and adopting customer-centric orientation is mainly discussed in relation to large corporations, but as the study shows it also affects SMEs. [Kotler et al. 2010; Brown, Brown 2014; Peppers, Rogers 2016]

Takes into account expectations of stakeholders

Follows law regulations and international business conduct

Acts ethically and this is enforced within the whole organization

Tries to minimalize the negative influence of its actions to environment

Tries to strengthen the positive influence of its actions to environment

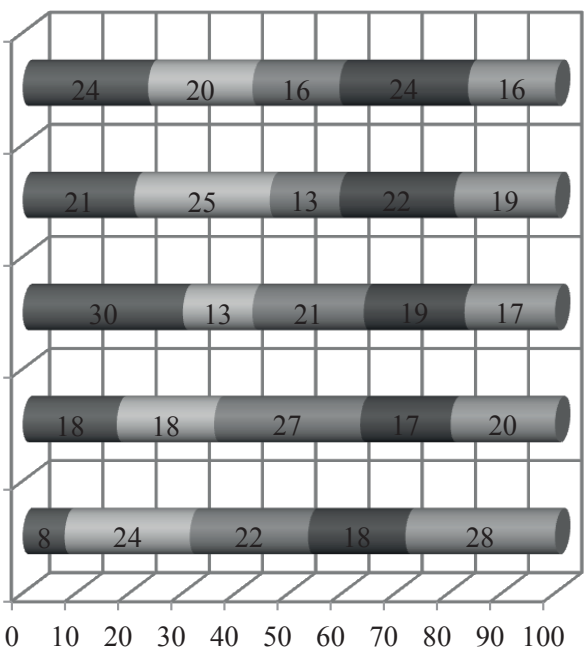

$\square$ I place $\square$ II place $\square$ III place $\square$ IV place $\square$ V place

Figure 2. Please specify all the actions undertaken by your company to carry out the strategy, having in mind the motives. My company: [\% of answers]

Source: empirical study, Institute of Management, Warsaw School of Economics 2016, n = 153 . 
The particular information about the enterprises does not heavily influence the general distribution of responses illustrated in Figure 2. For companies with limited liability taking into account the expectations of stakeholders seems to be more important than for stock corporations and companies which are run as single economic units. As $67 \%$ of companies with a majority of international capital decide to act in accordance with ethical principles (compared to 59\% of companies with the majority of Polish equity), so companies with the majority of Polish equity more often stress that they try to strengthen the positive impact of their operations on environment $(55 \%$ in comparison to $44 \%$ of companies with the majority of international capital). In a similar way, as $69 \%$ of small firms take into account the expectations of stakeholders (compared with $59 \%$ of medium companies) and $62 \%$ of small companies seek to enhance the positive impact of their operations on environment (compared with $45 \%$ of medium companies), medium-sized companies more often declare that they act in accordance with applicable law and international business conduct ( $71 \%$ vs. $56 \%$ of small firms).

\section{Level of maturity}

From the understanding of CSR and the activities undertaken by SMEs we can deduct the level of maturity of SMEs in the CSR context. The respondents had to estimate their involvement and try to decide whether it was more of operational (e.g. marketing-like) or strategic character.

Among the five options presented in Figure 3 one has been chosen by the vast majority of respondents. It concerns the statement that the company undertakes rather defensive actions, e.g. aimed at mitigating negative effects of its operations or avoiding administrative penalties (44\%). The second option assuming that the firm introduces CSR initiatives as a mean of marketing strategy, e.g. that are related to promotional initiatives, PR investments or image-building events, has been endorsed by two times smaller number of respondents $(21 \%)$. The smallest number of respondents $(8 \%)$ chose the most preferred option in which the company responded to CSR challenges in a systemic manner, by modifying its business model, rebuilding its product or service offering and appreciating value in sustainability.

These observations point to the lack of maturity of the SME sector. W. Visser identifies five levels of organizational maturity determining both the perception of CSR as well as the way the strategy is implemented, with regard to CSR ideas. [Visser, Hollender 2011; Visser 2012; Visser 2014] Responsible business has strategic and long-term value. It is based on the principles of social dialogue and the search for solutions beneficial both for the company and for its environment. [Dialog społeczny 2015] Decision to take mostly interventions aimed at mitigating the negative influence of operations on environment or at avoiding administrative penalties ranks Polish SMEs at the bottom of the "pyramid of maturity" built by W. Visser and shows that SMEs treat CSR as a necessity of business, enforced in many situations by external factors (such enforcement may take place in highly regulated sectors, for example 
food industry, when non-compliance with food processing or packaging standards is punishable) rather than an investment or added value. This is directly related to the ability to identify tangible, measurable benefits and risks associated with taking actions congruent with CSR ideas.

Undertakes rather defensive actions, e.g. aimed at mitigating negative effects of its operations or avoiding administrative penalties

Undertakes charity actions, organizes special-cause or environmetal-cause events

Introduces CSR initiatives as a mean of marketing strategy, e.g. that are related to promotional initiatives, PR investments or image-building events

CSR initiatives have strategic value, there is a clear linkage between tmem and the overall strategy, adequate management systems are implemented

Responds to CSR challenges in a systemic manner, by modifying its business model, rebuilding its product or service offering and appreciating value in sustainability

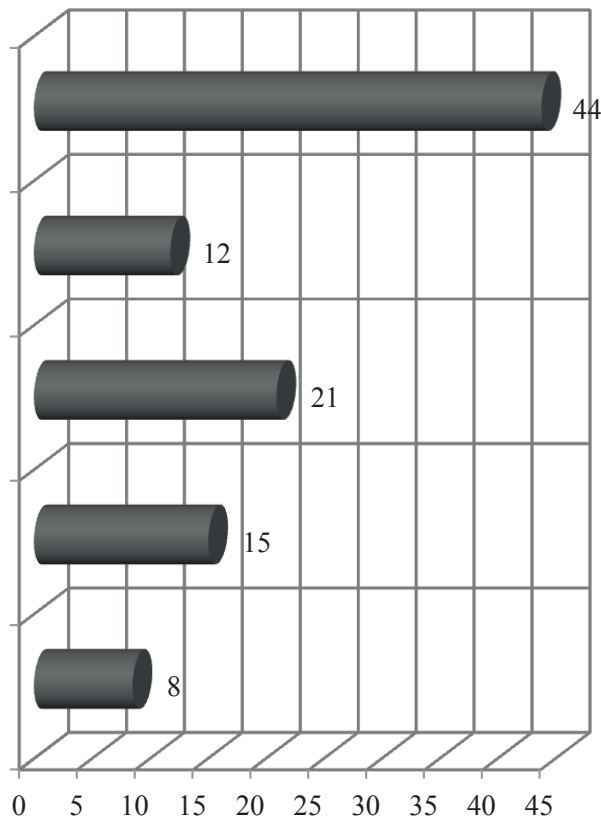

Figure 3. Which of the following best describes the level of conducted or intended activity of your company in the field of CSR? [\% of answers]

Source: empirical study, Institute of Management, Warsaw School of Economics 2016, n = 153.

Again, the particular information about the enterprises does not heavily influence the general distribution of responses illustrated in Figure 3. Minor deviations include for example the fact that none of the respondents describing themselves as a one-man business, undertakes charity actions, organizes special-cause or environmental-cause events, and not a single stock corporation responds to CSR challenges in a systemic manner. Companies with the majority of Polish equity more often acknowledge that they introduce CSR initiatives as a mean of marketing strategy, while companies with the majority of international capital more often see the relationship between CSR initiatives and their core operations and are much more likely to respond to CSR challenges in a systemic manner. In order to estimate the level of organizational maturity, the range of operations might play a role here. If we analyze the extremes, $40 \%$ of international companies take defensive actions (compared to $51 \%$ of domestic and $31 \%$ of regional 
firms), $10 \%$ of them respond to CSR challenges in systemic manner (compared to 5\% of domestic and $15 \%$ of regional companies). It can also be stated that more small companies than medium ones have a more mature approach to CSR: $32 \%$ of small companies see strategic or systemic value in CSR, compared to $15 \%$ of medium firms.

\section{Tools used in CSR engagement}

Having in mind general direction towards sustainability, SMEs use various tools to implement their strategy.

Actions for local community

Employee volunteering

Social campaigns that enable influencing community behavior through media

Programs for employees, e.g. investments in employee development

Social reporting, presenting management style d strategy fulfillment (including CSR engagement)

Socially responsible marketing, e.g. advertising ned with ethical norms and not raising controversy

Management systems, being transparent and effective

Green activities, aimed at environmental protection and reducing negative impact on environment

upply chain management, applying CSR principles at every stage of the supply and introcunig standards for contractors

Product labelling (eco labelling, social labelling)

Management systems that introduce green solutions for offices, headquarters and subsidiaries

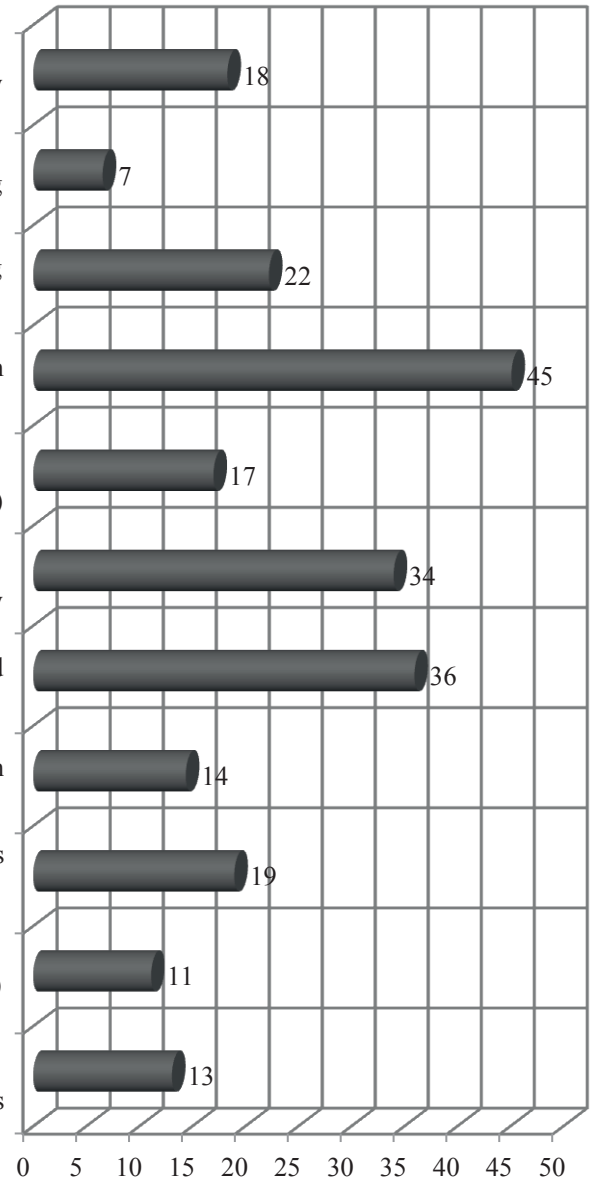

Figure 4. When engaging in CSR, the company uses (or plans to use) the following tools: [\% of answers] Source: empirical study, Institute of Management, Warsaw School of Economics 2016, n = 153. 
Of the eleven proposals presented in the cafeteria (see Figure 4), three gained a clear advantage over the other. SMEs decide to invest in programs for employees, e.g. in employee development in the first place when they implement particular tools supporting CSR ideas (45\%).

Fewer respondents introduce transparent and effective management systems (36\%) and socially responsible marketing practices (34\%). These actions are consistent with the understanding of sustainability presented in Figure 1. They also relate to the social component of CSR, which makes SMEs less focused on environmental issues. It may also be the case that SMEs do not see carrying out ecological initiatives as part of CSR. The economic component was not included in this question. Interestingly, $17 \%$ of respondents admitted to issuing social reports, understood as a way of presenting business management practices and a process in strategy implementation, including the socially responsible activities. This means not only making an effort to describe the activities of a company, but also using specific methodologies and indicators to measure progress in achieving targets.

Again, the particular information about the enterprises does not heavily influence the general distribution of responses illustrated in Figure 4. Actions for local community and the introduction of transparent and effective management systems were more important for manufacturing companies and companies with limited liability. A negligible percentage of trading firms choose employee volunteering. Companies with the majority of Polish equity more often use socially responsible marketing practices and stick to transparent and efficient management systems, while companies with the majority of international capital more often choose tools such as social reporting, green activities, aimed at environmental protection and reducing negative impact on environment, and management systems that introduce green solutions for offices, headquarters and subsidiaries. The biggest differences with regard to CSR tools used by small and medium enterprises relate to: actions for local community ( $22 \%$ v. $14 \%)$, socially responsible marketing ( $38 \%$ v. $30 \%)$, management systems $(30 \%$ v. $42 \%)$ and supply chain management (16\% v. $22 \%)$.

\section{Conclusions}

Questions raised and described in the article allow to build a CSR profile of small and medium enterprises in the context of the requirements of sustainable development as follows: The company takes into account social, environmental and economic issues in its decision making (Figure 1) by declaring to act ethically (Figure 2), but in reality it mainly undertakes defensive interventions aimed at mitigating a negative impact of its operations on environment or avoiding administrative penalties (Figure 3). It is a contradiction that can attest to the fact that companies are in the early stages of learning, adopting and implementing measures and mechanisms related to the requirements of sustainable development. But it certainly proves that the transition from declarations to actions is not obvious and easy. This may be in part dictated 
by the specific nature of SMEs, which are strongly exposed to the turmoil in the macro environment. For SMEs, the concentration on the economic component, which consists of such elements as market position, bargaining power in relation to business partners, opportunities for further development (by expansion, the search for niches, alliances or acquisitions), product/service offering expansion, is a clear priority, although the social component might be visible through SMEs willingness to deeply understand the needs of local communities and targeted markets and address them accordingly.

Similar characteristics of the company reveal the analysis of the CSR tools, though the tools used might result from the adaptation enforced by the requirements of sustainable development. The three most commonly used practices are as follows: investments in employee development through various programs $(45 \%)$, introduction of transparent and effective management systems (36\%) and following socially responsible marketing practices (34\%). These actions are consistent with the understanding of sustainability, presented in Figure 1, they also relate to the social component of CSR, which makes SMEs less focused on environmental issues.

Although the findings from the empirical study cannot be transferred onto the whole population of SMEs (as they are not representative), they signal some tendencies which might serve as guidelines for more extended research. They also support observations from previously held studies.

\section{References}

Bachnik K., 2016, Zrównoważony rozwój a małe i średnie przedsiębiorstwa, [in:] A. Skowronek-Mielczarek (ed.), Zarządzanie małymi i średnimi przedsiębiorstwami $w$ warunkach zrównoważonego rozwoju, Difin, Warszawa.

Brown L., Brown C., 2014, The Customer Culture Imperative: A Leader's Guide to Driving Superior Performance, McGraw-Hill, New York.

Daszkiewicz N., Wach K., 2013, Mate i średnie przedsiębiorstwa na rynkach międzynarodowych, Wyd. UE w Krakowie, Kraków.

Dialog społeczny, Społeczna odpowiedzialność przedsiębiorstw (CSR), http://www.dialog.gov.p1/ dialog-miedzynarodowy/spoleczna-odpowiedzialnosc-przedsiebiorstw-csr/ [access 29.06.2015].

Elkington J., 2004, Enter the triple bottom line, [in:] A. Henriques, J. Richardson (eds.), The Triple Bottom Line: Does It All Add Up, Taylor \& Francis, Abingdon-on-Thames, https://www. google.pl/url? $\mathrm{sa}=\mathrm{t} \& \mathrm{rct}=\mathrm{j} \& \mathrm{q}=\&$ esrc $=\mathrm{s} \&$ source $=$ web $\& \mathrm{~cd}=2 \& \mathrm{cad}=\mathrm{rja} \& u a c t=8 \& \mathrm{sqi}=2 \& \mathrm{ved}=0 \mathrm{ahU}$ KEwi_6Y-R0d3QAhUKq48KHdoOCRIQFggnMAE\&url=http\%3A\%2F\%2Fwww.johnelkington. com\%2Farchive\%2FTBL-elkington-chapter.pdf\&usg=AFQjCNGN57qOFqhiz1Yt-N3ItDga-GgSd wg\&bvm=bv.139782543,d.c2I (access 06.12.2016).

Elkington J., Zeitz J., 2014, The Breakthrough Challenge: 10 Ways to Connect Today's Profits With Tomorrow's Bottom Line, Jossey-Bass, Hoboken.

European Commission, 2011, Communication from the Commission to the European Parliament, the Council, the European Economic and Social Committee and the Committee of the Regions. A renewed EU strategy 2011-14 for corporate social responsibility, European Commission, Com 681 final, Brussels, 25.10.2011, http://eur-lex.europa.eu/LexUriServ/LexUriServ.do?uri= COM:2011:0681:FIN:EN:PDF (access 01.07.2015). 
James L., 2015, Sustainability Footprints in SMEs: Strategy and Case Studies for Entrepreneurs and Small Business, Wiley, Hoboken.

Kotler P., Kartajaya H., Setiawan I., 2010, Marketing 3.0: From Products to Customers to the Human Spirit, Wiley, Hoboken.

Peppers D., Rogers M., 2016, Managing Customer Experience and Relationships: A Strategic Framework, Wiley, Hoboken.

Przedsiębiorstwo, region, rozwój, 2011, M. Strużycki (ed.), Difin, Warszawa.

Savitz A., Weber K., 2014, The Triple Bottom Line: How Today's Best-Run Companies Are Achieving Economic, Social and Environmental Success - and How You Can Too, Wiley, Hoboken.

Sheehan M.J., 2013, Sustainability and the Small and Medium Enterprise (SME): Becoming More Professional, Xlibris, Bloomington.

Visser W., 2012, Corporate Sustainability \& Responsibility: An Introductory Text on CSR Theory \& Practice-Past, Present \& Future, Kaleidoscope Futures Ltd., Amazon.

Visser W., 2014, CSR 2.0: Transforming Corporate Sustainability and Responsibility, Springer, Kaleidoscope Futures Lab, London.

Visser W., Hollender J., 2011, The Age of Responsibility: CSR 2.0 and the New DNA of Business, Wiley, Hoboken. 